\title{
Penderitaan dari Sudut Pandang Teologi Injili
}

\author{
Marsi Bombongan Rantesalu \\ Institut Agama Kristen Negeri Kupang \\ marsibombongan@gmail.com
}

\begin{abstract}
Discussions on theology of suffering are very often discussed lately with the co-19 pandemic. There are a variety of different views that emerge to address the problem of suffering and disaster. This study aims to find out one view of suffering, that is, from the evangelicals. The method used in this research is descriptive qualitative using the literature as a source of data. From the results of the study the authors found that the evangelical view of suffering is that they consider suffering and disaster to be the will and sovereignty of God. In the suffering experienced by His people, God still shows His care. Evangelical groups also often associate disaster and suffering with eschatology.
\end{abstract}

Keywords: suffering; disasters; evangelicals; god's sovereignty; providensia

\begin{abstract}
Abstrak
Pembahasan mengenai teologi penderitaan sangat sering dibicarakan diakhir-akhir ini secara khusus dengan adanya pandemi covid-19. Ada berbagai pandangan berbeda yang muncul menyikapi masalah penderitaan dan bencana. Penelitian ini bertujuan untuk mencari tahu salah satu pandangan mengenai penderitaan yaitu dari kaum Injili. Metode yang digunakan dalam penelitian ini adalah deskriptif kualitatif dengan menggunakan literatur sebagai sumber datanya. Dari hasil penelitian penulis menemukan bahwa pandangan kaum injili mengenai penderitaan adalah mereka menganggap penderitaan dan bencana merupakan kehendak dan kedaulatan Allah. Di dalam penderitaan yang dialami umat-Nya, Allah tetap menunjukkan pemeliharaan-Nya. Kelompok Injili juga sering mengaitkan bencana dan penderitaan dengan akhir saman.
\end{abstract}

Kata Kunci: penderitaan; bencana; injili; kedaulatan allah; providensia 


\section{Pendahuluan}

Akhir tahun 2019 dunia dikejutkan dengan munculnya wabah virus mematikan yang bermula di provinsi Wuhan Tiongkok. Virus yang disebut Covid-19 tersebut kemudian menjadi pandemi yang melanda dunia. ${ }^{1}$ Fenomena ini berdampak terhadap semua lini kehidupan manusia baik dari segi ekonomi, sosial, pendidikan dan bahkan keagamaan. Berbagai kebijakan yang tidak populerpun diambil oleh pemerintah baik pusat maupun daerah dalam menyikapi pandemi ini seperti beribadah dari rumah yang kemudian dalam masyarakat khususnya gereja memunculkan pro dan kontra. ${ }^{2}$

Penderitaan melalui penyakit yang ditimbulkan oleh covid-19 tersebut kemudian mengundang reaksi para teolog memberikan pernyataan dan pandangan-pandangannya. John Piper pada masa pandemi menulis buku yang dalam bagiannya menjelaskan bahwa pandemi ini telah ditetapkan Allah dalam hikmat kebijaksanaan-Nya demi tujuan-tujuan yang baik meskipun harus ada penderitaan. ${ }^{3}$ Lennox dalam bukunya dengan optimis mengatakan bahwa virus corona dan semua penyakit yang pernah memporakporandakan dunia akan hilang akan tetapi mahkota kebenaran yang akan diberikan bagi mereka yang tetap mengasihi Tuhan Yesus tidak akan pernah pudar. Damai dalam pandemi hanya diperoleh dari Yesus. Hanya apakah keyakinan itu masih dimiliki setiap orang di dalam masa penderitaan seperti sekarang. ${ }^{4}$ Senada dengan itu, Tripp dalam bukunya menjelaskan bahwa penderitaan tidak selamanya oleh karena itu penderitaan bukanlah tuan atas kehidupan setiap orang, di dalam penderitaan selalu ada harapan dan pertolongan ditemukan karena Allah lebih dari segala hal buruk yang dialami. ${ }^{5}$

Pembahasan tentang teologi penderitaan atau teologi bencana kembali mencuat dimasa pandemi covid-19. Tema yang berkaitan dengan hal tersebut kemudian menjadi pokok yang menarik perhatian dalam dunia akademik maupun pastoral. 6 Tidak dapat dipungkiri bahwa pembahasan mengenai penderitaan dan bencana memunculkan persepsi yang beragam khususya ketika membicarakan pertanyaan tentang Teodice. Teologi penderitaan atau teologi bencana merupakan upaya untuk menjawab pertanyaan tersebut dengan pendekatan iman. ${ }^{7}$ Tentu saja jawaban terhadap pertanyaan mengenai bencana atau penderitaan tidak akan mendapatkan jawaban yang instan apalagi sebuah jawaban pasti yang memuaskan.

Dalam beberapa penelitian yang telah dilakukan sebelumnya telah dibahas beberapa topik berkaitan dengan penderitaan dari sudut pandang dan pendekatan yang berbeda. Kurniadi membahas mengenai bagaimana seorang katolik menghadapi penderitaan dengan

1“Data Global Dunia Covid 19 - Penelusuran Google,” accessed July 6, 2020, https://www.google.com/search?q=data+global+dunia+covid+19\&oq=Data+globar\&aqs=chrome.3. 69i57j017.11582j0j7\&sourceid=chrome\&ie=UTF-8. (Hingga penulisan makalah ini terkonfirmasi Covid19 telah menjangkiti 11,4 juta orang di seluruh dunia, 6,16 juta sembuh dan 534 ribu orang yang meninggal.

${ }^{2}$ Alexander Stevanus Luhukay, "ANALISIS TEOLOGIS MENGENAI BERIBADAH DI

RUMAH DI TENGAH PANDEMI COVID-19 DI INDONESIA," VISIO DEI: JURNAL TEOLOGI KRISTEN 2, no. 1 (May 6, 2020): 45, accessed July 6, 2020, http://jurnal.sttstarslub.ac.id/index.php/js/article/view/87.

3John Piper, Corona Virus and Christ (Surabaya: Literatur Perkantas Jatim, 2020), 93.

4John C. Lennox, Where Is God in A Corona Virus World? (Surabaya: Literatur Perkantas Jatim, 2020), 75-76.

5Paul David Tripp, Suffering (Penderitaan) (Surabaya: Literatur Perkantas Jatim, 2020), 214.

6Pembahasan Mengenai Teologi Penderitaan Menjadi Tema Dalam Mata Kuliah Colloquium Teologicum Pada Program Pascasarjana STFT Jaffray 2020.Juga Dalam Beberapa Webinar Yang Dilaksanakan Oleh Pdt. Agus Santoso, 2020.

7Zakaria J. Ngelow, TeologiBencana (Jakarta: BPK GunungMulia, 2019), 3. 
inspirasi dari Ayub. ${ }^{8}$ Pamungkas membahas penderitaan dari sudut pandang filosofis dan teologis. ${ }^{9}$ Stevanus menguraikan bagaimana seseorang menyadari akan kehadiran Allah melalui penderitaan yang dialami. ${ }^{10}$ Kewuel membahas bagaimana melihat Tuhan dibalik penderitaan. ${ }^{11}$ Sedangkan Gunawan melihat penderitaan dari konsep teodice C.S. Lewis. ${ }^{12}$

Persamaan kajian ini dengan penelitian sebelumnya yaitu pada metode penelitiannya yang menggunakan deskriptif kualitatif. Yang membedakannya adalah dalam pembahasan ini penulis mencoba melihat penderitaan dalam perspektif Injili sehingga melalui penelitian ini diharapkan akan memberikan gambaran tentang penderitaan dalam konsep teologi Injili.

\section{Metode Penelitian}

Metode yang digunakan penulis dalam penelitian ini adalah literature Review. Penulis menggunakan sumber data penelitian dari Alkitab, buku-buku referensi dan jurnaljurnal yang relevan dengan tema yang dibahas penulis. Berdasarkan obyek kajian penelitian ini, maka penulis menempuh beberapa tahap untuk mendapatkan data yang akan dibahas antara lain: pertama, mencatat beberapa pembahasan mengenai konsep penderitaan yang terdapat dalam Alkitab, buku-buku dan jurnal-jurnal terbaru. Kedua, penulis mencari referensi mengenai konsep penderitaan menurut kaum Injili. Ketiga, menganalisis hasil temuan tersebut dan keempat penulis menarik sebuah kesimpulan dari hasil pembahasan.

\section{Hasil dan Pembahasan Masalah Penderitaan}

Dalam sejarah Alkitab dapat disaksikan bahwa Allah sejak semula merancangkan hal yang baik bagi manusia dan ciptaan yang lain, Dia menciptakan segala sesuatu baik adanya (Kej.1-2). Demikian juga Allah merancangkan kebaikan bahkan rela merendahkan diri-Nya untuk demi keselamatan manusia (Fil.2:6-11). Dalam konteks ini dapat dilihat bahwa Allah yang maha baik adalah pencipta segala yang baik. Penderitaan sendiri secara terminologi diartikan sebagai suatu keadaan yang menyedihkan atau sakit yang harus ditanggung. ${ }^{13}$ Jika penderitaan adalah sesuatu yang menyedihkan atau menyakitkan berarti bahwa hal itu tidak berasal dari Allah. ${ }^{14}$ Baukham mengatakan "The kinds of suffering which are involved in human personal relations include compassion, in which the lover suffers sympathetically with the

8Bartholomeus Wahyu Kurniadi, "Inspirasi Kisah Ayub bagi Seorang Katolik dalam Menghadapi Penderitaan," MELINTAS 31, no. 1 (July 22, 2015): 47-62, accessed April 19, 2020, http://journal.unpar.ac.id/index.php/melintas/article/view/1455.

${ }^{9}$ Paulus Glorie Pamungkas, "KEJAHATAN DAN PENDERITAAN : TINJAUAN FILOSOFIS DAN TEOLOGIS" (2016): 13.

${ }^{10}$ Kalis Stevanus, "Kesadaran Akan Allah Melalui Penderitaan Berdasarkan Ayub 1-2," DUNAMIS: Jurnal Teologi dan Pendidikan Kristiani 3, no. 2 (April 29, 2019): 111-134, accessed April 19, 2020, https://www.sttintheos.ac.id/e-journal/index.php/dunamis/article/view/182.

${ }^{11}$ Hipolitus Kristoforus Kewuel, "MEMANDANG TUHAN DARI BALIK PENGALAMAN KEJAHATAN, PENDERITAAN, DAN KEMATIAN," JPAK: Jurnal Pendidikan Agama Katolik 4, no. 2 (2010): 264-278, accessed April 19, 2020, https://ejournal.widyayuwana.ac.id/index.php/jpak/article/view/103.

${ }^{12}$ Esther Gunawan, "Meneropong Makna Penderitaan Manusia Menurut Konsep Teodise C.S. Lewis," Veritas 16, no. 1 (2017): 17-32, accessed July 3, 2020,

https://www.neliti.com/publications/286218/meneropong-makna-penderitaan-manusia-menurutkonsep-teodise-cs-lewis.

${ }^{13}$ Tim Penyusun KBBI, “Kamus Besar Bahasa Indonesia," 5, n.d., s.v. "Penderitaan."

${ }^{14}$ Elvin Atmaja Hidayat, "Iman di Tengah Penderitaan: Suatu Inspirasi Teologis-Biblis

Kristiani," MELINTAS 32, no. 3 (2016): 286, accessed April 19, 2020,

http://journal.unpar.ac.id/index.php/melintas/article/view/2695. 
beloved who is suffering, and it is the divine sympathy which comes to the fore especially in discussions which focus on the problem of human suffering. A stronger form of sympathy is active solidarity with the suffering person, where the lover actually shares the situation from which the beloved is suffering."15Pernyataan Baukham ini mempertegas bahwa sumber penderitaan tidak berasal dari Allah.

Bencana dan penderitaan merupakan bagian dalam hidup manusia yang tidak dapat dihentikan atau dihindari sepenuhnya. Namun demikian, terkadang masih banyak orang yang tidak menyadari dan menerima bahwa hidupnya tidak akan pernah luput dari penderitaan. ${ }^{16}$ Penderitaan akan menjadi masalah manusia bahkan merupakan masalah teologi Kristen yang tidak akan terselesaikan sampai kapanpun. ${ }^{17}$ Yang terpenting adalah adalah sikap setiap orang dalam menghadapi atau menerima penderitaan tersebut. Stevanus mengatakan penderitaan sudah menjadi masalah iman, sebagian orang mampu untuk menerima sebuah penderitaan dan membuatnya semakin dekat kepada Tuhan ketika dia diuji melalui penderitaan tetapi tidak jarang yang tidak dapat menerima penderitaan yang membuatnya kehilangan imannya. ${ }^{18}$

\section{Teodice}

Jika dalam pembahasan sebelumnya dikatakan bahwa penderitaan atau bencana itu tidak berasal dari Allah maka pertanyaan yang muncul adalah dari manakah asal penderitaan itu? Tidak mudah untuk menjawab pertanyaan tersebut apabila di sisi lain menganggap Allah adalah baik dan segala yang diperbuat-Nya baik adanya. Upaya memberi jawaban rasional terhadap pertanyaan mengapa Tuhan mengijinkan kejahatan memunculkan konsep teodice. ${ }^{19}$ Kata teodise berasal dari kata theos yang berarti Tuhan dan dike Yang memiliki arti mengadili atau keputusan pengadilan sehingga secara harafiah teodise berarti mengadili Tuhan. ${ }^{20}$ Bagi Tambasco, teodice ini merupakan sebuah kontruksi dari filsafat untuk memberi jawaban terhadap masalah kejahatan dan penderitaan terhadap keberadan Allah yang maha baik. ${ }^{21}$

Ada beberapa pandangan yang berkaitan dengan teodise. Pandangan Ireneus yang dirumuskan ulang oleh John Hick mengatakan Kejahatan adalah buatan jiwa yang bertujuan untuk menuntun orang untuk semakin bermoral dan dekat dengan Tuhan. Thomas Aquinas melihat kejahatan sebagai suatu kekurangan. Kejahatan tidak berada pada dirinya, tetapi melalui pemahaman tentang hubungan dengan orang atau hal lain. David Hume menjelaskan bahwa Kekuasaan Tuhan tak terbatas sehingga apa saja yang dikehendaki akan dilakukan-Nya. Kebijaksan Tuhan tidak terbatas sehingga membuatnya tidak pernah salah dalam menentukan dan menggunakan sarana apapun untuk tujuan-Nya. Realitas yang terjadi bahwa alam cenderung tidak berpihak pada kebahagiaan manusia sehingga dipahami bahwa itu dibuat buka demi tujuan manusia tetapi tujuan Tuhan. Gottfried Leibniz yang memperkenalkan istilah teodise dalam karyanya

${ }^{15}$ Richard Bauckham, "“Only the Suffering God Can Help'. Divine Passibility in Modern

Theology," Themelios 9, no. 3 (1984): 6-12, accessed July 7, 2020,

https://www.theologicalstudies.org.uk/article_god_bauckham.html.

16Kurniadi, "Inspirasi Kisah Ayub bagi Seorang Katolik dalam Menghadapi Penderitaan," 49.

${ }^{17}$ Kewuel, "MEMANDANG TUHAN DARI BALIK PENGALAMAN KEJAHATAN,

PENDERITAAN, DAN KEMATIAN," 266.

${ }^{18}$ Stevanus, "Kesadaran Akan Allah Melalui Penderitaan Berdasarkan Ayub 1-2," 113.

${ }^{19}$ Alvin Plantiga, God, Freedom, and Evil (Michigan: William B. Eerdmans Publishing

Company, 1970), 10.

20“MEMPERTIMBANGKAN TEODISE LEIBNIZ Limen” (n.d.): 5, accessed July 13, 2020,

http://jurnal.stft-fajartimur.ac.id/index.php/lim/article/view/16.

${ }^{21}$ Anthony J. Tambasco, The Bible on Suffering (New York: Paulist Press, 2002), 1. 
Essais de Théodicée sur la bonté de Dieu, la liberté de l'homme et l'origine du mal berpendapat bahwa dunia adalah yang terbaik yang diciptakan oleh Tuhan. Leibniz juga berpendapat bahwa Tuhan tidak sewenang-sewenang dalam menggunakan kekuasaannya, tidak seperti yang terlihat oleh manuasia dalam berbagai bentuk kejahatan yang ada. ${ }^{22}$ Dari berbagai pandangan diatas jelas bahwa penderitaan dan bencana sangat berkaitan erat dengan kejahatan sehingga memunculkan pendapat yang mengatakan bencana dan penderitaan terjadi akibat dari kejahatan manusia.

Pada kajian penulis tidak akan fokus mengkaji pandangan-pandangan mengenai teodice atau memberi kritik terhadap pandangan tersebut tetapi menjadikan pemikiran tersebut sebagai dasar teori untuk melihat pemahaman lain tentang penderitaan. Adapun pandangan lain yang dimaksudkan adalah konsep menurut kaum injili yang akan dibahas pada bagian berikut.

\section{Konsep Penderitaan Menurut Kaum Injili}

Pada bagian ini penulis akan membahas bagaimana kaum injili melihat penderitaan atau bencana yang dialami oleh setiap orang. Adapun pandangan tersebut sangat berkaitan dengan konsep-konsep teologis yang akan diuraikan seperti berikut:

\section{Allah Berdaulat di Atas Penderitaan}

Dalam kalangan kaum injili (Evangelical) terdapat pandangan teologi yang begitu berpengaruh yaitu Calvinisme. ${ }^{23}$ Penganut paham Kalvin dikenal pada penekanan ajarannya mengenai kedaulatan Allah yang mutlak. ${ }^{24}$ pemahaman Calvinisme mengenai kedaulatan Allah biasanya disandingkan pada pembahasan mengenai konsep keselamatan bahwa Allah berketetapan dalam kedaulatan dan anugerah-Nya menyelamatkan manusia. Orang-orang injili sebagai penganut Calvinisme sangat memahami tentang konsep kedaulatan Allah tersebut.

Berkitan dengan kedaulatan Allah, Daun memaparkan dua permasalahan kedaulatan Allah yang berkaitan dengan manusia. Pertama, kedaulatan Allah berkaitan dengan keputusan-Nya tidak boleh diartikan sama dengan arogansi atau kesewenang-wenangan Allah sebab Dia juga adil dalam kedaulatan-Nya. Allah berdaulat penuh tetapi di sisi yang lain apa yang diputuskan dan ditentukan-Nya tidak berlawanan dengan keadilan-Nya. Kedua, kedaulatan Allah tidak melanggar ketetapan yang telah ditentukan-Nya. ${ }^{25}$ Pemaparan ini jelas memberikan penekanan yang kuat terhadap otoritas Allah yang tidak pernah salah dalam setiap ketetapan dan tindakan-Nya dan pada saat yang sama tidak mengesampingkan keadilan-Nya.

Mengenai topik kejahatan, bencana dan penderitaan Calvin meyakini bahwa semua itu terjadi untuk memenuhi kehendak Allah dan semuanya itu telah ditetapkan oleh Allah. Calvin berpendapat bahwa Allah dalam kedaulatan-Nya itu seringkali menggunakan instrumen-instrumen yang menjadi jalan dalam menggenapkan setiap tujuan-Nya, hal ini yang sering di sebutdengan penyebab sekunder. Penyebab sekunder merupakan segala sesuatu yang dipakai Allah sebagai alat untuk menggenapkan

22“MEMPERTIMBANGKAN TEODISE LEIBNIZ | Limen,” 9-10.

${ }^{23}$ Meskipun demikian sebagian kaum inlili dipengaruhi oleh paham Armenian yang penekanannya pada tanggung jawab manusia.

${ }^{24}$ Paulus Daun, "SEPUTAR MASALAH KEDAULATAN ALLAH DAN TANGGUNG JAWAB MANUSIA:", JurnalAmanatAgung 4, no. 1 (June 1, 2008): 34, accessed July 9, 2020, https://ojs.sttaa.ac.id/index.php/JAA/article/view/274.

${ }^{25}$ Daun, "SEPUTAR MASALAH KEDAULATAN ALLAH DAN TANGGUNG JAWAB MANUSIA." 
pemerintahan-Nya. Penyebab sekunder bisa dalam bentuk apa saja yang merupakan bagian dari ciptaan-Nya. Menurut Calvin, semua peristiwa yang terjadi adalah kehendak Allah, baik terjadi melalui perantara ataupun peristiwa yang diatur oleh Allah secara langsung, yang kadang kala secara logika bertentangan dengan perantara itu sendiri. Penekanan Calvin bahwa segala sesuatu yang terjadi dan dialami dalam alam semesta terjadi karena perintah Allah bahkan hukum alam pun merupakan bagian dari kedaulatanNya. ${ }^{26}$ Senada dengan itu Evans, mengatakan Kedaulatan Allah berhubungan dengan apa yang telah Dia atur atas alam semesta dan atasnya Dia melakukan pengawasan yang mutlak bagi semua ciptaan-Nya. Allah memiliki otoritas tertinggi atas segala kejadian dan peristiwa yang dialami oleh manusia. Sebagai yang maha kuasa Dia berdaulat atas segala sesuatu terjadi baik yang secara langsung disebabkan-Nya maupun yang diisinkan-Nya terjadi. ${ }^{27}$

Atas dasar paham mengenai kedaulatan Allah, kaum Injili kemudian menganggap setiap penderitaan dan bencana yang terjadi juga adalah dalam kehendak dan kedaulatan Allah. Allah melakukan segala sesuatu itu baik dalam ukuran-Nya sendiri. Allah mengijinkan bencana alam, sakit penyakit yang bahkan mengambil nyawa manusiapun sebagai bagian dari rencana-Nya.

\section{Di dalam Penderitaan ada Pemeliharaan Allah (Providensia Allah)}

Secara terminologi providensia Allah dapat diartikan sebagai pemeliharaan Allah atas seluruh manusia dan ciptaan-Nya. Grudem mengatakan Providensi Allah merupakan penyertaan Allah bagi manusia dan semua ciptaan yang lain tanpa henti dengan cara memeliharanya, selain itu Allah bekerjasama dengan ciptaan-Nya tersebut dalam segala sesuatu yang dilakukan, Allah juga mengarahkan semua ciptaan tersebut untuk tetap berada dalam koridor yang harusnya dilakukan, dan Allah tetap mengarahkan ciptaan-Nya supaya berada tetap dalam tujuan Allah. ${ }^{28}$ Allah memiliki kuasa dalam mengatur segala yang terjadi atas ciptaan-Nya dan Ia juga tetap melanjutkannya dengan memelihara semua ciptaan-Nya, dalam segala hal Allah mengarahkan kepada tujuan-Nya sendiri. ${ }^{29}$

Munculnya pemahaman bahwa Allah memelihara umat-Nya senantiasa, tentu saja memiliki dasar biblis yang kuat. Taanyid mengatakan, dasar Alkitab yang dipakai dalam menjelaskan providensia Allah adalah Matius 6:26;10:30, yang mengatakan bahwa segala sesuatu yang terjadi pada ciptaan-Nya diketahui oleh Allah dan Allah memelihara mereka sesuai dengan kehendak-Nya. ${ }^{30}$ Selain itu peristiwa yang terjadi menimpa Ayub merupakan pelajaran dan pengalaman yang penting bahwa Allah terus menyertai umat-Nya dalam masalah seberat apapun yang dialami. Dalam peritiwa Ayub mengajarkan apabila Allah mengijinkan umat-Nya mengalami bencana atau penderitaan, ada batas-batas tertentu yang telah ditetapkan oleh Tuhan. Lazor dkk mengatakan, ketika Iblis diijinkan oleh Allah mencobai Ayub, ia tetap tunduk pada kekuasaan-Nya yang mutlak, hal ini menggambarkan bagaimana kekuasaan Allah atas Iblis dimana ia tidak dapat memperlakukan Ayub di luar batas-batas yang telah ditentukan oleh Allah. ${ }^{31}$

${ }^{26}$ Jessica Novia Layantara, “DETERMINISME, MASALAH KEJAHATAN DAN PENYEBAB SEKUNDER MENURUT JOHN CALVIN," Jurnal Amanat Agung 11, no. 2 (December 1, 2015): 316, accessed July 9, 2020, https://ojs.sttaa.ac.id/index.php/JAA/article/view/181.

27Tonny Evans, Teologi Allah: Allah Kita Maha Agung (Malang: Gandum Mas, 1999), 105.

${ }^{28}$ Wayne Grudem, Systematic Theology -An Introduction to Biblical Doctrine (England:

Intervarsity Press, 1994).

${ }^{29}$ John M. Frame, Doctrine of God (New Jersey: P\&R Publishing, 2002).

30ParelTanyit, "Providensia Allah dan Kehendak Bebas Manusia," JurnalJaffray 2, no. 2 (April

2, 2005): 78, accessed July 9, 2020, https://ojs.sttjaffray.ac.id/JJV71/article/view/162.

${ }^{31}$ W.S. Lasor, D.A. Hubbrad, and F.W. Bush., Pengantar Perjanjian Lama (Jakarta: BPK Gunung Mulia, 2015), 140. 
Kaum injili sangat meyakini bahwa penderitaan dan bencana yang terjadi kepada manusia khususnya bagi umat-Nya ada dalam kehendak Allah. Tidak ada suatupun yang secara kebetulan atau terjadi diluar pengetahuan Allah. Stevanus mengatakan bahwa kita patut bersyukur karena Kristus telah menjadi milik umat-Nya yang menderita dan mati di kayu Salib sebagai bagian dari rencana Allah bagi semua manusia. Penderitaan Kristus seharusnya dijadikan sebuah refleksi bagi orang percaya bahwa ketika mau mengikut Kristus harus siap memikul salib, yaitu bersedia mengalami penderitaan karena nama-Nya dan menderita karena kebenaran. Sesungguhnya Allah dengan kekuasaan-Nya mampu melindungi umat-Nya agar tidak menderita, tetapi Allah lebih fokus pada perlindungan karakter umat-Nya dibanding melindungi apa pun juga. Perlindungan Allah tentu saja sesuai dengan kedaulatan-Nya, bagi kebaikan umat itu sendiri menurut pandangan-Nya. ${ }^{32}$

Konsep pemeliharaan Allah ditengah-tengah penderitaan, bencana dan penyakit yang dialami tentu saja tidak mudah dimengerti oleh pemikiran manusia yang sangat terbatas sehingga kemudian menjadi gampang menyalahkan Tuhan sebagai yang jahat. Kaum Injili percaya bahwa penderitaan tidak berasal dari Allah tetapi diijinkan-Nya terjadi karena ada maksud Allah yang lebih baik terhadap umat-Nya dan di balik semua itu kebaikan dan pemeliharaan Allah tetap ada. Kongguasa menjelaskan, pada waktu orang percaya mengalami kejahatan, penderitaan dan bencana, maka seharusnya mereka memercayai tentang adanya kebijaksanaan serta kebaikan Allah meskipun akal manusia sangat terbatas dalam memahami apa yang menjadi maksud Allah diantara semuanya itu. Orang percaya harus bermegah di dalam penderitaan (Rom.5:3-5), karena selalu ada pengharapan yang tidak pernah mengecewakan bagi setiap orang yang percaya, pengharapan yang berasal dari Allah sendiri. Allah hadir dalam segala sesuatu dengan kebijaksanaan, kemahatahuan, kebaikan dan kemahakuasan-Nya. ${ }^{33}$

\section{Penderitaan dan Bencana Berkaitan dengan Eskatologi}

Ketika membahas tentang penderitaan dan bencana seperti pandemi covid-19 ternyata ada banyak orang yang langsung mengaitkannya dengan akhir zaman (Eskatologi). Pada dasarnya pendapat seperti itu muncul dari penganut premilenial. Premilenialisme merupakan pandangan yang mempercayai akan kedatangan Yesus sebelum kerajaan seribu tahun. ${ }^{34}$ Dari segi cara menafsirkan nubuat premilenialisme kemudian terbagi menjadi dua yaitu premilenialisme dispensasional yang tafsirannya sangat harafiah dan premilenialisme historika yang penafsirannya cenderung lebih rohani. ${ }^{35}$

Penganut premilenialisme dispensasional sangat yakin dengan adanya tribulasi (kesusahan besar). Faot dan kawan-kawan mengatakan Tribulasi atau merupakan masa dimana Tuhan akan menyelesaikan penghakiman-Nya bagi dunia yang berdosa. Masa siksaan itu merupakan masa selama tujuh tahun pada akhir saman, di mana pada masa ini Allah akan mengadakan penghakiman-Nya terhadap semua orang menolak-Nya. Selain itu Allah akan menyempurnakan rencana keselamatan-Nya bagi Israel. Tribulasi ini sesuai dengan penglihatan nabi Daniel (Dan 9:2427). Adapun jumlah 144.000 orang Yahudi merupakan yang pertama (Why 14:4) bagian israel yang telah dinubuatkan untuk

32Stevanus, "Kesadaran Akan Allah Melalui Penderitaan Berdasarkan Ayub 1-2," 130.

${ }^{33}$ Herny Kongguasa, "Masalah Kejahatan dan Pemeliharaan Allah," Jurnal Jaffray 2, no. 2 (April 2, 2005): 72, accessed July 9, 2020, https://ojs.sttjaffray.ac.id/JJV71/article/view/161. ${ }^{34}$ Marsi Bombongan Rantesalu, DOKTRIN KERAJAAN SERIBU TAHUN BERDASARKAN KITAB WAHYU, preprint (AgriXiv, October 14, 2019), accessed January 21, 2020, https:/ /osf.io/cpvjr. ${ }^{35}$ Charles C. Ryrie, Teologi Dasar, II (Yogyakarta: Yayasan ANDI, 2004). 
memperoleh penebusan (Zak 12:10; Rom 11:25-27). ${ }^{36}$ Terjadinya bencana dan penderitaan yang terjadi merupakan bagian dari prosesi yang mendahului kedatangan Kristus di bumi untuk mendirikan kerajaannya. Peter Wongso menjelaskan tentang keadaan-keadaan yang dituliskan dalam kitab Wahyu pasal 6 mengenai ketujuh materai, wahyu pasal 8 dan 9 tentang tujuh sangkakala dan Wahyu pasal 15-16 mengenai tujuh cawan murka Allah adalah merupakan penderitaan yang begitu dahsyat yang merupakan tanda kemenangan Kristus yang sempurna dan segera sesudahnya Kristus akan segera datang mendirikan kerajaanNya. ${ }^{37}$

Tentu saja bencana dan penderitaan yang terjadi tidak sepenuhnya sesuai dengan konsep tribulasi yang dijelaskan diatas khususnya mengenai lama masa tribulasi tersebut. Meski demikian kaum dispensasional sering mengaitkan setiap bencana dan penderitaan dengan akhir saman dengan dasar bahwa Kristus akan segera datang yang kedua kali dan peristiwa yang mendahuluinya pasti terjadi.

\section{Implikasi}

Di tengah perdebatan dan permasalahan mengenai penderitaan atau bencana, kaum injili mengemukakan pandangannya yang sangat prinsip. Sikap tersebut tentu saja berimplikasi terhadap pandangan teologi kaum injili di dalam menghadapi penderitaan. Allah memiliki otoritas atas ciptaan-Nya termasuk apa yang terjadi terhadap ciptaan-Nya. Dampak yang lain bagi orang percaya bahwa adanya bencana dan penderitaan membuat orang percaya untuk semakin mendekatkan diri kepada sang pemilik otoritas tertinggi, memiliki kesetiaan kepada-Nya, dan bertanggung jawab atas ciptaan yang lain.

\section{Rekomendasi untuk Penelitian Lanjutan}

Penelitian ini tidak sempurna dari segi metodologi maupun dari segi jangkauan pembahasan yang sangat terbatas hanya pada studi literatur. Oleh sebab itu, penulis merekomendasikan untuk penulis berikut yang tertarik membahas tema ini supaya dapat turun ke lapangan untuk meneliti dengan mengambil data langsung dari para teolog atau penganut paham Injili untuk mencari tahu lebih jauh mengenai pandangan mereka yang lebih dalam tentang kejahatan, penderitaan, dan bencana. Penelitian berikutnya diharapkan dapat menyempurnakan penelitian ini dari beberapa segi.

\section{Kesimpulan}

Berdasarkan hasil pembahasan dalam penelitian ini, maka penulis menarik kesimpulan bahwa kelompok Injili tidak memberikan sebuah jawaban yang gamblang mengenai pertanyaan dalam konsep teodice mengenai mengapa penderitaan itu terjadi, darimana asalnya dan apakah Allah yang menciptakan kejahatan. Penelitian ini menemukan jawaban yang sangat teologis mengenai pemahaman Injili tentang kejahatan dan penderitaan, bahwa semuanya ada dalam kehendak dan kedaulatan-Nya. Kaum Injili meyakini bahwa dalam setiap penderitaan dan bencana Allah hadir dalam kebijaksanaan, kemahakuasaan, dan kebaikan-Nya, serta tetap memelihara umat-Nya meskipun hal tersebut sangat sulit dipahami oleh pemikiran manusia yang terbatas. Selain itu, kelompok Injili sering mengaitkan terjadinya bencana dan penderitaan dengan akhir zaman sebagai salah satu bagian prosesi kedatangan Kristus yang kedua kali.

${ }^{36}$ Agustinus Faot et al., "Bertahan Sampai Kesudahan Akan Diselamatkan," Journal KERUSSO 4, no. 1 (March 29, 2019): 15-25, accessed July 13, 2020, http:/ /jurnal.sttiisurabaya.ac.id/index.php/Kerusso/article/view/102.

${ }^{37}$ Peter Wongso, Hermeneutika Eskatologi (Malang: SAAT, 1996), 50. 


\section{Rujukan}

Bauckham, Richard. "'Only the Suffering God Can Help'. Divine Passibility in Modern Theology." Themelios 9, no. 3 (1984): 6-12. Accessed July 7, 2020.

https://www.theologicalstudies.org.uk/article_god_bauckham.html.

C. Lennox, John. Where Is God in A Corona Virus World? Surabaya: Literatur Perkantas Jatim, 2020.

C. Ryrie, Charles. Teologi Dasar. II. Yogyakarta: Yayasan ANDI, 2004.

Daun, Paulus. "SEPUTAR MASALAH KEDAULATAN ALLAH DAN TANGGUNG JAWAB MANUSIA:" Jurnal Amanat Agung 4, no. 1 (June 1, 2008): 33-41. Accessed July 9, 2020. https://ojs.sttaa.ac.id/index.php/JAA/article/view/274.

David Tripp, Paul. Suffering (Penderitaan). Surabaya: Literatur Perkantas Jatim, 2020.

Evans, Tonny. Teologi Allah: Allah Kita Maha Agung. Malang: Gandum Mas, 1999.

Faot, Agustinus, Jonathan Octavianus, Juanda Juanda, and Daniel Ari Wibowo. "Bertahan Sampai Kesudahan Akan Diselamatkan." Journal KERUSSO 4, no. 1 (March 29, 2019): 15-25. Accessed July 13, 2020. http://jurnal.sttiisurabaya.ac.id/index.php/Kerusso/article/view/102.

Frame, John M. Doctrine of God. New Jersey: P\&R Publishing, 2002.

Grudem, Wayne. Systematic Theology -An Introduction to Biblical Doctrine. England: Intervarsity Press, 1994.

Gunawan, Esther. “Meneropong Makna Penderitaan Manusia Menurut Konsep Teodise C.S. Lewis." Veritas 16, no. 1 (2017): 17-32. Accessed July 3, 2020. https://www.neliti.com/publications/286218/meneropong-makna-penderitaanmanusia-menurut-konsep-teodise-cs-lewis.

Hidayat, Elvin Atmaja. “Iman di Tengah Penderitaan: Suatu Inspirasi Teologis-Biblis Kristiani." MELINTAS 32, no. 3 (2016): 285-308. Accessed April 19, 2020. http://journal.unpar.ac.id/index.php/melintas/article/view/2695.

Kewuel, Hipolitus Kristoforus. "MEMANDANG TUHAN DARI BALIK PENGALAMAN KEJAHATAN, PENDERITAAN, DAN KEMATIAN." JPAK: Jurnal Pendidikan Agama Katolik 4, no. 2 (2010): 264-278. Accessed April 19, 2020. https://ejournal.widyayuwana.ac.id/index.php/jpak/article/view/103.

Kongguasa, Herny. “Masalah Kejahatan dan Pemeliharaan Allah.” Jurnal Jaffray 2, no. 2 (April 2, 2005): 53-76. Accessed July 9, 2020. https://ojs.sttjaffray.ac.id/JJV71/article/view/161.

Kurniadi, Bartholomeus Wahyu. "Inspirasi Kisah Ayub bagi Seorang Katolik dalam Menghadapi Penderitaan." MELINTAS 31, no. 1 (July 22, 2015): 47-62. Accessed April 19, 2020. http://journal.unpar.ac.id/index.php/melintas/article/view/1455.

Lasor, W.S., D.A. Hubbrad, and F.W. Bush. Pengantar Perjanjian Lama. Jakarta: BPK Gunung Mulia, 2015.

Layantara, Jessica Novia. “DETERMINISME, MASALAH KEJAHATAN DAN PENYEBAB SEKUNDER MENURUT JOHN CALVIN." Jurnal Amanat Agung 11, no. 2 (December 1, 2015): 297-332. Accessed July 9, 2020. https://ojs.sttaa.ac.id/index.php/JAA/article/view/181.

Luhukay, Alexander Stevanus. “ANALISIS TEOLOGIS MENGENAI BERIBADAH DI RUMAH DI TENGAH PANDEMI COVID-19 DI INDONESIA." VISIO DEI: JURNAL TEOLOGI KRISTEN 2, no. 1 (May 6, 2020): 43-61. Accessed July 6, 2020. http://jurnal.sttstarslub.ac.id/index.php/js/article/view/87.

Ngelow, Zakaria J. Teologi Bencana. Jakarta: BPK Gunung Mulia, 2019.

Pamungkas, Paulus Glorie. "KEJAHATAN DAN PENDERITAAN : TINJAUAN FILOSOFIS DAN TEOLOGIS” (2016): 13.

Piper, John. Corona Virus and Christ. Surabaya: Literatur Perkantas Jatim, 2020. 
Plantiga, Alvin. God, Freedom, and Evil. Michigan: William B. Eerdmans Publishing Company, 1970.

Rantesalu, Marsi Bombongan. DOKTRIN KERAJAAN SERIBU TAHUN BERDASARKAN KITAB WAHYU. Preprint. AgriXiv, October 14, 2019. Accessed January 21, 2020. https://osf.io/cpvjr.

Stevanus, Kalis. “Kesadaran Akan Allah Melalui Penderitaan Berdasarkan Ayub 1-2." DUNAMIS: Jurnal Teologi dan Pendidikan Kristiani 3, no. 2 (April 29, 2019): 111-134. Accessed April 19, 2020. https://www.sttintheos.ac.id/ejournal/index.php/dunamis/article/view/182.

Sugiyono. Metode Penelitian Pendidikan: Pendekatan Kuantitatif, Kualitatif, Dan RED. Bandung: Alfabeta, 2016.

Tambasco, Anthony J. The Bible on Suffering. New York: Paulist Press, 2002.

Tanyit, Parel. "Providensia Allah dan Kehendak Bebas Manusia." Jurnal Jaffray 2, no. 2 (April 2, 2005): 77-85. Accessed July 9, 2020. https://ojs.sttjaffray.ac.id/JJV71/article/view/162.

Tim Penyusun KBBI. “Kamus Besar Bahasa Indonesia.” 5, n.d.

Wongso, Peter. Hermeneutika Eskatologi. Malang: SAAT, 1996.

"Data Global Dunia Covid 19 - Penelusuran Google." Accessed July 6, 2020. https:// www.google.com/search?q=data+global+dunia+covid+19\&oq=Data+globar \&aqs $=$ chrome.3.69i57j017.11582j0j7\&sourceid $=$ chrome\&ie $=U T F-8$.

“MEMPERTIMBANGKAN TEODISE LEIBNIZ | Limen” (n.d.). Accessed July 13, 2020. http://jurnal.stft-fajartimur.ac.id/index.php/lim/article/view/16.

Pembahasan Mengenai Teologi Penderitaan Menjadi Thema Dalam Mata Kuliah Colloquium Teologicum Pada Program Pascasarjana STFT Jaffray 2020. Juga Dalam Beberapa Webinar Yang Dilaksanakan Oleh Pdt. Agus Santoso., n.d. 